\title{
Management Practices and Production Constraints of Indigenous Somali Cattle Breed in Shabelle Zone, Somali Regional State, Ethiopia
}

\author{
Abdihakim Ma'alin*, Kawnin Abdimahad, Guled Hassen, Abdulahi Mahamed, Mahamed Hassen \\ Department of Animal and Range Sciences, Jigjiga University, Jigjiga, Ethiopia \\ Email: *ciwal667@gmail.com
}

How to cite this paper: Ma'alin, A., Abdimahad, K., Hassen, G., Mahamed, A. and Hassen, M. (2022) Management Practices and Production Constraints of Indigenous Somali Cattle Breed in Shabelle Zone, Somali Regional State, Ethiopia. Open Journal of Animal Sciences, 12, 103-117.

https://doi.org/10.4236/ojas.2022.121008

Received: August 29, 2021

Accepted: January 18, 2022

Published: January 21, 2022

Copyright $\odot 2022$ by author(s) and Scientific Research Publishing Inc. This work is licensed under the Creative Commons Attribution International License (CC BY 4.0).

http://creativecommons.org/licenses/by/4.0/

\begin{abstract}
This study was conducted in Shabelle zone of Somali Regional State to assess management practices and production constraints of indigenous Somali Cattle. A total of 200 household heads were selected from four cattle potential districts; Dhanan, Ber'ano, Godey \& Adadle. The relevant information was collected through semi-structured questionnaire, focus group discussion, key informants interview, and personal observations. Majority of the respondents were illiterate. The average cattle holding size was 8.97 heads/household and cattle were mainly kept for milk production. The major feed resources in the study area were natural pasture and crop residue, and communal grazing was the most important feeding system in the area. Feed shortage was a problem hindering cattle production in the study area during dry season mainly January up to March. Animals traveled long distances to watering points ( $>5 \mathrm{~km}$ ) during dry season, while in wet season, animals were watered in nearby water sources. Cattle housing was open kraal fenced with the thorned plenty acacia trees and calves were housed separately from other cattle. Breeding in the study area was uncontrolled and was bred with their own or neighbors' bull. Age at first mating, age at first calving and calving interval were 3.25 years, 4.05 years and 16.56 months, respectively. The daily milk yield and lactation length were 2.22 liters and 8.07 months, respectively. The production and reproduction performance of Somali cattle was relatively higher than other local breeds in the country mainly in terms of milk yield and fertility potential under the existing environmental conditions. The major constraints of cattle production were feed shortage, disease, water scarcity, lack of veterinary services, marketing problem and predator. Among those constraints, inadequate supply of quality feed, diseases and water shortage were the main reasons for
\end{abstract}


low productivity of cattle and are the major factors limiting productivity. Therefore, to sustain the production system in the study areas, it is recommended to improve the current condition of communal rangelands through management of degraded areas by awareness creation on the value of these common resources and development of rules and regulation to sustain the existing resource and implement over the utilization of communal/pastoral rangeland management systems to reduce constraints such as shortage of feed, drought and grazing land deterioration which perpetuated through time due to land-use changes and seasonal fluctuation).

\section{Keywords}

Cattle Production, Reproductive Performance, Constraints, Management Practices

\section{Introduction}

In Ethiopia, livestock is an integral part of agriculture and the contribution of live animals and their products to the agricultural economy accounts for $47 \%$ [1]. Livestock performs multiple functions in the Ethiopian economy by providing food, input for crop production and soil fertility management, raw material for industry, cash income as well as in promoting saving, fuel, social functions, and employment. The total cattle population for the country is estimated to be about 65.35 million [2]. Out of this, the female cattle constitute 54.68 percent and the remaining 45.32 percent, are male cattle. It is estimated that 97.76 percent of the total cattle in the country are local breeds and the remaining are hybrid and exotic breeds that accounted for 1.91 percent and 0.32 percent, respectively [2].

Despite the largest cattle population, reproductive and productive performance is very low. The country's per capita milk consumption is estimated to be about $19.2 \mathrm{~kg}$ per year, which is far below the average per capita consumption of Africa, $37.2 \mathrm{~kg}$ per year [3]. Livestock productivity in Ethiopia is said to be poor due to a number of reasons among which, the low genetic capacity of the indigenous cattle for milk and meat production is a major one [4]. In Ethiopia, the poor genetic potential for productive traits, substandard feeding, poor health care and management practices, are the main contributors to low productivity [5]. Productive and reproductive traits are crucial factors determining the profitability of cattle production [6].

Ethiopia has immense potential for increasing livestock production, both for local use and for export purposes. However, expansion and productivity were constrained by inadequate and imbalanced nutrition, sporadic disease outbreak, scarcity of water, lack of appropriate livestock extension services, insufficient and unreliable data to plan the services, and inadequate information to improve animal performance, marketing, processing and integration with crop and natu- 
ral resources for sustainable productivity and environmental health [7].

Understanding the current overall management practices and major constraints is critical for implementing appropriate corrective interventions that will lead to increased productivity of indigenous cattle. This necessitates the need for specific databases to be generated under specific production scenarios. So far, little research has been conducted to identify the overall cattle management practices and major production constraints in the Shabelle zone. Thus, this study aimed to fill a knowledge gap that currently exists. As a result, the objective of this study was to assess management practices and production constraints of indigenous cattle, as well as to suggest potential solutions to the identified production constraints.

\section{Materials and Methods}

\subsection{Description of the Study Area}

Shabelle is one of the eleven zones of the Somali Regional State, Ethiopia. It is bordered on the west by Afder, on the north by Fiq, on the northeast by Korahei, and on the south by the Provisional Administrative Line with Somalia. The Shabelle River runs through this zone. The attitude is 250 to 600 meters above sea level. The main rainy season termed locally as $G u^{\prime}$ (spring) in Somali language extends from April to June and the short rainy seasons Deyr (autumn) stretches from October to December. The mean maximum and minimum annual temperatures are $35^{\circ} \mathrm{C}$ and $22.9^{\circ} \mathrm{C}$, respectively. The mean annual rainfall of the areas is 150 to $344.06 \mathrm{~mm}[8]$.

\subsection{Sampling Technique and Sample Size}

Multi-stage purpose sampling technique was employed to select the districts and kebeles for the study. Study districts were stratified based on agro ecology in to strata. Based on secondary source of information, Dhanan, Ber'ano, Godey and Adadle districts of the Zone were selected for actual data collection. Eight kebeles (two from each district) were selected purposively based on cattle population potential, agroecology and accessibility. Therefore, a total of four woredas, eight kebeles and 200 households were studied.

\subsection{Data Sources and Collection Procedure}

Both primary and secondary data were collected by using semi-structured questionnaire, focus group discussions, key informant interviews and personal observations. Some of the important variables collected in the questionnaire were: socio-economic characteristics of the house hold (sex, age and educational status of the respondents), production objectives, management aspects (composition of the flock, watering, feeding systems, housing, health issues), and production and reproductive performances of cattle, and major constrains of cattle production. Additional information regarding the general cattle production system, major constraints and the appropriate interventions perceived for the future improve- 
ment of cattle husbandry in the study area were also gathered through focus group discussions. Secondary information was collected by reviewing documented sources and communications with the regional, zonal and district livestock and rural development offices, metrological stations, and reliable published and unpublished documents.

\subsection{Data Analysis}

Data were analyzed using SPSS version 20. Ranking the livestock species based on their level of importance were carried out using the formula to compute the index as employed by Musa et al. [9].

\section{Results and Discussion}

\subsection{Household Characteristics}

Table 1 shows sex, age, educational status and family size of the respondents in the study area. Majority of the respondents were males (75.5\%) while the rest (24.5\%) were females. This result is in line with Guyo and Tamir [10] and Gebreegziabher et al. [11] who reported that majority of cattle owners in Burji and Humbo districts of southern Ethiopia were males. The average age of the respondents was 41.39 years old. Majority (63.5\%) of the respondents were illiterate. The higher percentage of illiteracy is similar with the finding of Wendimu [12] who reported a higher proportion of illiteracy and religious schools' education for Godey and Adadle districts of Somali region. The role of education is obvious in affecting household income, adopting technologies, demography, health, and as a whole the socio-economic status of the family as well [13]. The overall average family size of the districts was $6.41 \pm 1.3$.

Table 1. Gender, age, educational level and family size of the respondents (\%).

\begin{tabular}{cccccc}
\hline \multirow{2}{*}{ Variable } & \multicolumn{5}{c}{ District } \\
\cline { 2 - 6 } & Dhanan & Ber'ano & Goday & Adadle & Overall \\
\hline Gender & & & & & \\
Male & & 78 & 60 & 80 & 75.5 \\
Female & 16 & 22 & 40 & 20 & 24.5 \\
Age & $40.4 \pm 9.08$ & $42.7 \pm 8.6$ & $39.32 \pm 9.1$ & $43.11 \pm 7.3$ & $41.3 \pm 8.5$ \\
$\begin{array}{c}\text { (Mean } \pm \text { SD) } \\
\text { Educational level }\end{array}$ & & & & & \\
Illiterate & 64 & 68 & 56 & 66 & 63.5 \\
$\begin{array}{c}\text { Primary grades } \\
\text { Religious school }\end{array}$ & 26 & 20 & 36 & 22 & 26 \\
$\begin{array}{c}\text { Family size } \\
\text { (Mean } \pm \text { SD) }\end{array}$ & 10 & 12 & 8 & 12 & 10.5 \\
\hline
\end{tabular}




\subsection{Livestock Holding Size}

The livestock species owned by the households in the study area were sheep, goat, camel, cattle and donkey (Table 2). The overall average cattle holding size was 8.97 heads/household. The mean livestock holding was significantly different $(P<0.05)$ among study districts. Godey and Ber'ano districts had a higher cattle holding size than Dhanan and Adadle districts. This might be due to the livestock feed availability and environmental conditions.

\subsection{Purpose of Cattle Rearing}

The purpose of keeping cattle in the study districts are presented in Figure 1. In the study districts, about $68 \%, 70 \%, 67 \%$ and $71 \%$ of the respondents in Dhanan, Ber'ano, Godey and Adadle were used for main purpose of cattle rearing in milk production, respectively. On other hand, the other important purpose of cattle rearing in the study districts were selling of live cattle for income generation followed by draught purpose and social/cultural function. Most of the respondents in the study areas reported the milk production as the primary purpose for keeping cattle followed by income source. According to Scarpa et al. [14], in developing countries, especially in low input smallholder production system, the most valuable livestock attributes are often those that successfully guarantee

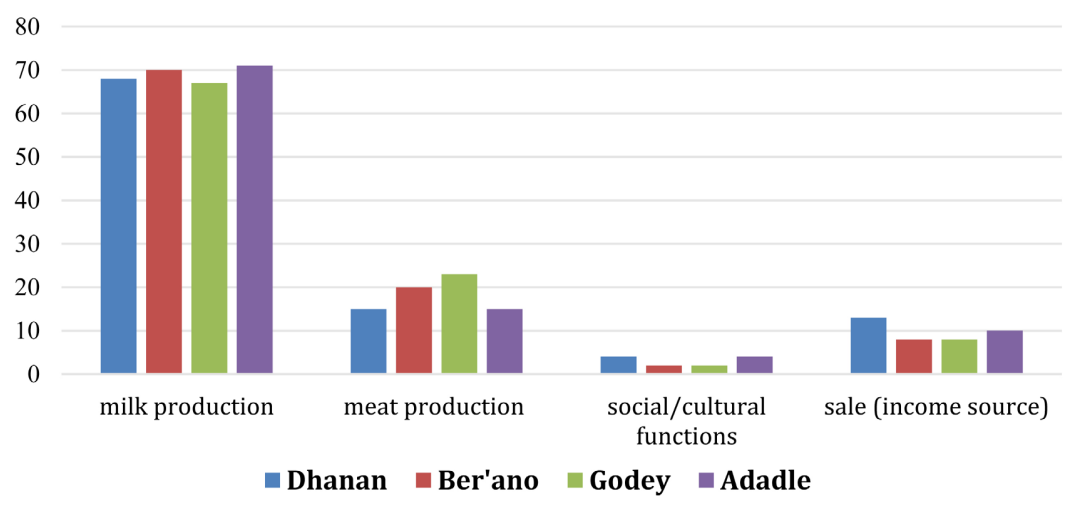

Figure 1. Proportion of respondents to purpose of cattle rearing in the study area.

Table 2. Livestock species composition (Mean \pm SE) in the study area.

\begin{tabular}{cccccc}
\hline \multirow{2}{*}{ Species } & \multicolumn{5}{c}{ District } \\
\cline { 2 - 5 } & Dhanan & Ber'ano & Godey & Adadle & Overall \\
\hline Sheep & $27.4 \pm 1.5^{\mathrm{b}}$ & $28.7 \pm 1.7^{\mathrm{a}}$ & $25.4 \pm 1.5^{\mathrm{c}}$ & $27.2 \pm 1.5^{\mathrm{b}}$ & $27.1 \pm 0.7$ \\
Goats & $27.1 \pm 1.3^{\mathrm{a}}$ & $24.6 \pm 1.4^{\mathrm{c}}$ & $23.4 \pm 1.3^{\mathrm{d}}$ & $26.5 \pm 1.3^{\mathrm{b}}$ & $25.4 \pm 0.6$ \\
Cattle & $7.2 \pm 0.6^{\mathrm{d}}$ & $9.6 \pm 0.8^{\mathrm{b}}$ & $10.7 \pm 0.3^{\mathrm{a}}$ & $8.9 \pm 0.70^{\mathrm{c}}$ & $8.9 \pm 0.3$ \\
Camel & $5.8 \pm 0.7^{\mathrm{b}}$ & $4.8 \pm 0.3^{\mathrm{c}}$ & $4.5 \pm 0.4^{\mathrm{d}}$ & $6.22 \pm 0.5^{\mathrm{a}}$ & $5.3 \pm 0.5$ \\
Donkey & $1.08 \pm 0.08$ & $1.1 \pm 0.07$ & $1.11 \pm 0.05$ & $1.02 \pm 0.04$ & $1.08 \pm 0.06$ \\
\hline
\end{tabular}

Means followed by different superscript letters in the same row are significantly different at $(P<0.05)$. 
multi functionality, flexibility and resilience in order to deal with variable environmental conditions.

\subsection{Management Practices of Cattle}

\subsubsection{Feed Resources and Availability}

The common feed resources reported in the study districts were natural pasture and crop residue. Grazing land in the studied areas were entirely communally owned (Table 3) the most abundant feed source for cattle in the areas though grazing drastically reduces in the dry season. The majority of the respondents (88.5\%) were reported that natural pasture was the major feed resource during wet season. This is because, grassing land provide the major source of feed in both wet and dry seasons and extensive system of grazing is the grazing system practiced in the study districts. The remaining respondents were reported that crop residual was the other feed resource utilized during wet season. This study agrees with the report of Teshome et al. [15] in Rayitu district; natural pasture and tree branch were the main feed resource during wet season. This finding also in line with the report of Alemayehu [16] who reported that the livestock feed resource in Ethiopia is natural pasture.

\subsubsection{Months of Feed Shortage}

The months of the feed shortage in the study districts are presented in Figure 2.

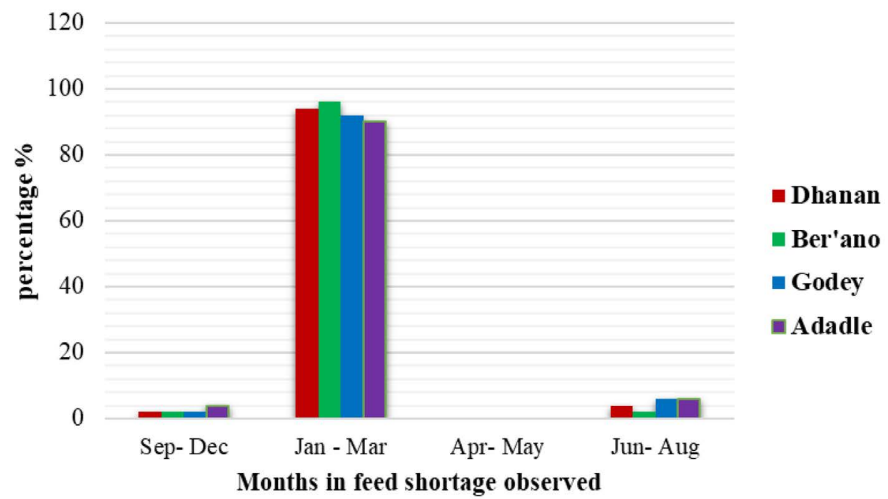

Figure 2. Months of feed shortage in the study districts.

Table 3. Feed resources in wet and dry seasons (\%) in the study area.

\begin{tabular}{cccccc}
\hline Variables & \multicolumn{5}{c}{ District } \\
\cline { 2 - 6 } & Dhanan & Ber'ano & Godey & Adadle & Overall \\
\hline Wet season & & & & & \\
Natural pasture & 96 & 80 & 86 & 92 & 88.5 \\
Crop residue & 4 & 20 & 14 & 8 & 11.5 \\
Dry season & & & & & \\
Natural pasture & 76 & 60 & 56 & 68 & 65 \\
Crop residue & 24 & 30 & 36 & 24 & 28.5 \\
Improved forages & - & 10 & 8 & 8 & 6.5 \\
\hline
\end{tabular}


The majority of the respondents indicated that feed shortage was observed the months of January-March in both study districts. These months mentioned the respondents were the month of drought.

\subsubsection{Feed Utilization and Conservation Practices}

The major constraints associated with crop residues utilization for livestock feeding were collection, transportation, storage and feeding problems. Although natural pasture and crop residues were produced, their full and efficient utilization for livestock feeding has been hindered partly by inadequate knowledge of the farmers. Indeed, some farmers had a great concern to store the crop residues in a separate cottage constructed houses merely for storage of crop residues or on the roof in their cottages and on their farm land. Such farmers are observed to efficiently utilize these feed resources which they give to their animals bunch by bunch. The residues are piled in stacks near homesteads and animals were let to eat from the stacks or given small quantities in the morning and evening, or for working oxen, before and after work. Alternatively, the residues are left in the threshing ground and consumed by animals together with the standing straws which are left for aftermath grazing. Thus, feed conservation practice causes huge wastage of feed on ground as during feeding and when rain starts residues rotten on ground. This finding agrees with the study of Vernooij [17].

\subsubsection{Water Source and Availability}

The distribution and types of watering facilities varied and influenced the frequency of watering and distance travelled in search of water bodies are presented in (Table 4). The survey revealed that majority of the respondents (62\%) reported that Shebele River were the major water source during both wet and dry season except Dhanan District that Borehole was the major water source during both wet and dry season. This finding in Ber'ano, Godey and Adadle districts agreed with the previous study conducted by Tesfaye [18] who reported that major water sources in Metema district was river and contrast with the finding of Dhanan district which majority of the respondents use boreholes. The variation of water source in the districts was the availability of river in the different study areas. Because of that river was not available in Dhanan district.

The survey result indicated that water shortage existed in months of January to end march in Dhanan district while no such water shortage in other study districts, because of the availability of Shebele river. With regard to the frequency of watering of cattle, majority of the respondents water their animals Once in two days (87\%) in the study districts. While the remaining respondents, $(10.5 \%$ and $2.5 \%$ ) once in a day and adlibtum respectively. The survey result indicated that distance travelled for watering cattle majority of the respondents were travelled 1 - $5 \mathrm{~km}$ and remaining respondents were travelled (40\% and 11\%) for 6 $10 \mathrm{~km}$ and less than $1 \mathrm{~km}$ respectively this finding was comparable with previous study conducted by Tilahun et al. [19] who reported that pastoralists in Shinile zone traveled a distance of $(7.59 \mathrm{~km})$ and those in Jigjiga zone traveled $(6.06 \mathrm{~km})$ 
Table 4. Water sources in wet and dry seasons (\%).

\begin{tabular}{|c|c|c|c|c|c|}
\hline \multirow{2}{*}{ Variables } & \multicolumn{5}{|c|}{ District } \\
\hline & Dhanan & Ber'ano & Godey & Adadle & Overall \\
\hline \multicolumn{6}{|l|}{ Wet season } \\
\hline River & - & 76 & 82 & 90 & 62 \\
\hline Pond & 30 & - & - & - & 7.5 \\
\hline Borehole & 38 & - & - & - & 9.5 \\
\hline Streams & 10 & - & - & - & 2.5 \\
\hline Temporary water source & 22 & 24 & 18 & 10 & 18.5 \\
\hline \multicolumn{6}{|l|}{ Dry season } \\
\hline River & - & 100 & 100 & 100 & 75 \\
\hline Pond & 20 & - & - & - & 5 \\
\hline Borehole & 80 & - & - & - & 20 \\
\hline \multicolumn{6}{|l|}{ Frequency of watering } \\
\hline Once in a day & - & 20 & 6 & 16 & 10.5 \\
\hline Once in two days & 100 & 76 & 94 & 78 & 87 \\
\hline Ad-libitum & - & 4 & - & 6 & 2.5 \\
\hline \multicolumn{6}{|c|}{ Distance travelled to watering points } \\
\hline$<1 \mathrm{~km}$ & 4 & 10 & 14 & 16 & 11 \\
\hline $1-5 \mathrm{~km}$ & 30 & 58 & 48 & 60 & 49 \\
\hline $6-10 \mathrm{~km}$ & 66 & 32 & 38 & 24 & 40 \\
\hline
\end{tabular}

in single trip. Another study by IPS [20] indicated that the distance from residential areas to watering points varied from 2 to $70 \mathrm{~km}$, and this had significant influences on the frequency of watering.

\subsubsection{Cattle Herding}

During the day, the majority of the respondents herded their cattle alone (apart from other animals). Whereas $17.5 \%$ of respondents herded cattle with shoats, and $7.5 \%$ herded cattle with other livestock. The majority $(71.5 \%)$ of respondents reported that children herded cattle, while $19.5 \%$ reported that men herded cattle and $9 \%$ reported that women herded. This is in line with previous studies of Fikru and Omer [21] who reported that children were the main source of labour for herding livestock in Awbarre and Shinile districts of Somali region, respectively (Table 5).

\subsubsection{Cattle Housing}

Cattle pens were mostly open kraals surrounded by thorny acacia trees, and barns were uncommon (Figure 3). In addition, calves were kept isolated from the rest of the cattle. In Ethiopia, diverse livestock species are mostly housed in 


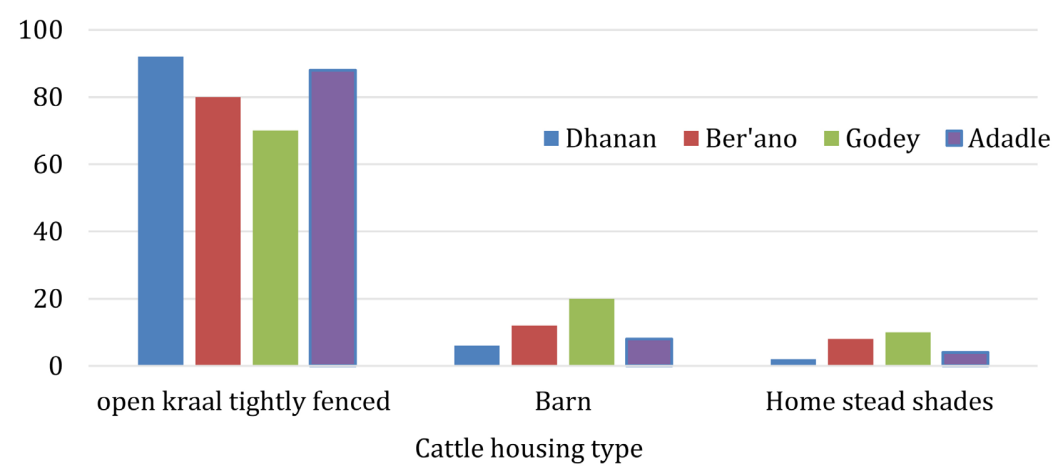

Figure 3. Cattle housing type in the study districts.

Table 5. Herding of cattle in the study area (\%).

\begin{tabular}{cccccc}
\hline \multirow{2}{*}{ Variables } & \multicolumn{5}{c}{ District } \\
\cline { 2 - 6 } & Dhanan & Ber'ano & Godey & Adadle & Overall \\
Cattle herding & 60 & 70 & 90 & 80 & 75 \\
Alone & 20 & 10 & 8 & 12 & 17.5 \\
Together with shoats & 20 & 5 & 2 & 8 & 7.5 \\
Together with other livestock & & & & & \\
Herding person & 54 & 76 & 90 & 66 & 71.5 \\
Children & 30 & 18 & 8 & 22 & 19.5 \\
Men & 16 & 6 & 2 & 12 & 9 \\
Women & & &
\end{tabular}

open fenced barns with no roofs to shelter larger livestock such as cattle (excluding calves), camels, and donkeys at night [18].

\subsubsection{Cattle Breeding System}

Two types of mating systems, referred as controlled and uncontrolled natural mating systems, were practiced in the study areas. Accordingly, most of the herders (84.5\%) used uncontrolled natural mating system while the rest (15.5\%) used controlled natural mating system (Table 6). This is in line with the study of Philimon et al. [22] who reported $60.9 \%$ of uncontrolled natural mating system for cattle herders in Afar region. Similarly, Mulugeta [23] reported that $73.1 \%$ of cattle herders in Humera ranch practiced uncontrolled breeding system. Majority of the herders (61.5\%) used their own bull for breeding purpose, and the rest (23.5\%) relied on neighbors' bulls. This could be one of the reasons why both mating systems prevailed in the study districts. This was in line with Kohler and Orber [24] who reported that farmers in East Africa exchanged genetic material freely.

\subsubsection{Milking and Calf Rearing Practices}

Calves were grazed and housed separately from the dams except when calves 
Table 6. Mating system and source of bull used for cattle breeding (\%).

\begin{tabular}{cccccc}
\hline \multirow{2}{*}{ Variables } & \multicolumn{5}{c}{ District } \\
\cline { 2 - 6 } & Dhanan & Ber'ano & Godey & Adadle & Overall \\
\hline Mating system & 18 & 16 & 8 & 20 & 15.5 \\
Controlled & 82 & 84 & 92 & 80 & 84.5 \\
Uncontrolled & 66 & 60 & 64 & 56 & 61.5 \\
Source of bull & 34 & 40 & 36 & 44 & 38.5 \\
Own bull & & & & & \\
Neighbors bull & 34 & & & & \\
\hline
\end{tabular}

were used to stimulate milk let-down. Traditional hand milking was the only type of milking practice in the study areas. Washing of udder before and after milking was not practiced and milking was mostly done by women. Traditionally, calves were allowed to suckle their dams before (to initiate milk letdown) and after milking (to drain whatever was left in the udder).

\subsubsection{Cattle Diseases}

Pneumonia, pasteurolosis, lumpy skin disease, tuberculosis, blackleg, and wooden tongue were the most common cattle diseases in the study locations. Similarly, there was an issue with animal health care. Lack of veterinary drugs, less frequent animal health care, remoteness of animal health centers, lack of qualified animal health technicians, and lack of animal health facilities were the most commonly cited animal health issues.

\subsection{Reproductive and Productive Performance of Cattle}

The average age at first mating, first calving, and calving interval were 3.25 years, 4.05 years, and 16.56 months, respectively (Table 7). However, the analysis showed slight significance differences of some attributes among study areas and this could be attributed to feed availability and management conditions.

The average age at puberty of Somali cattle was a bit lower than that of Afar cattle (3.5 years) as reported by Philimon et al. [22]. The average age at first calving for Somali cattle was 4 years which is lower than Sheko breed 54.1 months [25]. The average calving interval in this study was 16.56 months, which is shorter than the calving interval of Begait cattle (22 months) as reported by Merha [26]. Al-Amin et al. [27] reported calving interval of 14.7 months for North Bengal cattle breed in Bangladesh, which is shorter than the average calving interval of the present study. Masama et al. [28] noted that the management factor especially nutrition determines pre-pubertal growth rate and reproductive development.

The average daily milk offtake of Somali cattle was 2.22 liters, which is higher than the report from the survey done in Oromia Regional State with average daily milk yield of 1.4 liters [29] and report on-farm daily milk yield of 1.8 and 
Table 7. Reproductive and productive performance of cattle (Mean \pm SE).

\begin{tabular}{|c|c|c|c|c|c|}
\hline \multirow{2}{*}{ Variables } & \multicolumn{5}{|c|}{ District } \\
\hline & Dhanan & Ber'ano & Godey & Adadle & Overall \\
\hline $\begin{array}{l}\text { Age at first mating } \\
\qquad(\mathrm{yrs})\end{array}$ & $3.30 \pm 0.06$ & $3.24 \pm 0.05$ & $3.14 \pm 0.05$ & $3.33 \pm 0.06$ & $3.25 \pm 0.03$ \\
\hline $\begin{array}{l}\text { Age at first calving } \\
\qquad(\mathrm{yrs})\end{array}$ & $4.11 \pm 0.04^{\mathrm{a}}$ & $4.03 \pm 0.04^{\mathrm{b}}$ & $3.95 \pm 0.02^{c}$ & $4.14 \pm 0.06^{\mathrm{a}}$ & $4.05 \pm 0.02$ \\
\hline $\begin{array}{l}\text { Calving interval } \\
\text { (months) }\end{array}$ & $16.42 \pm 0.07$ & $16.46 \pm 0.07$ & $16.36 \pm 0.06$ & $17.02 \pm 0.06$ & $16.56 \pm 0.03$ \\
\hline $\begin{array}{l}\text { Lactation length } \\
\text { (months) }\end{array}$ & $7.98 \pm 0.1$ & $8.08 \pm 0.1$ & $8.36 \pm 0.1$ & $7.86 \pm 0.1$ & $8.07 \pm 0.05$ \\
\hline $\begin{array}{l}\text { Daily milk off-take } \\
\text { (l) }\end{array}$ & $2.10 \pm 0.07$ & $2.19 \pm 0.09$ & $2.58 \pm 0.07$ & $2.01 \pm 0.08$ & $2.22 \pm 0.04$ \\
\hline
\end{tabular}

Means followed by different superscript letters in the same row are significantly different at $(P<0.05), \mathrm{SE}=$ Standard Error, NS $=$ Not Significant.

1.9 liters per day for Raya Sanga and Wello highland zebu cattle [30]. However, it was a bit smaller than the report of Mulugeta [23] for Begait cattle which was 2.52 liters. The differences might be due to breed/type variation and management factors especially nutrition and geographical location.

The average lactation length in this study was 8.07 months, which is longer than the 7.29 months reported by Kedija et al. [31] for local cattle in the Mieso district of Oromia Regional State. It was, however, lower than the finding of Kedir et al. [32], who found a lactation time of 10 months for Somali cattle. It's possible that the observed variances are due to management, breed and environmental factors.

\subsection{Cattle Production Constraints}

In the study locations, feed shortage, disease, water scarcity, lack of veterinary services, marketing problem and predator were cited as key cattle production constraints (Table 8). Among the constraints, feed shortage, disease and water scarcity were considered as the most important problems ranked first, second and third, respectively. Philimon et al. [22] cited that main constraints of cattle production in Afar region include feed and water shortage, drought, diseases, predator, shortage of veterinary services and market problem.

\section{Conclusion and Recommendations}

Cattle were reared for different purposes including milk production, income source, meat and social and cultural functions. Natural pasture was the most common feed resource during wet and dry seasons, and grazing land was communal. During the dry season, however, the quantity and quality of the natural pastures decrease and fail to meet nutrient requirements for good performance. River (Wabi Shabelle), bore wells and pond water were the major sources of 
Table 8. Constraints of cattle production in the study area.

\begin{tabular}{ccccc}
\hline \multirow{2}{*}{ Constraints } & \multicolumn{4}{c}{ District } \\
\cline { 2 - 5 } & $\begin{array}{c}\text { Dhanan } \\
\text { Index }\end{array}$ & $\begin{array}{c}\text { Ber'ano } \\
\text { Index }\end{array}$ & $\begin{array}{c}\text { Godey } \\
\text { Index }\end{array}$ & $\begin{array}{c}\text { Adadle } \\
\text { Index }\end{array}$ \\
\hline Feed shortage & 0.30 & 0.30 & 0.24 & 0.22 \\
Disease & 0.24 & 0.22 & 0.21 & 0.20 \\
Water scarcity & 0.19 & 0.21 & 0.16 & 0.16 \\
Predator & 0.11 & 0.12 & 0.11 & 0.11 \\
Market problem & 0.12 & 0.10 & 0.12 & 0.13 \\
Lack of veterinary service & 0.18 & 0.17 & 0.13 & 0.15 \\
\hline
\end{tabular}

water in the study area. Shortage of water was common in dry season as compared to wet season. Cattle houses were open kraal tightly fenced with thorned plenty acacia trees. Uncontrolled mating was common in the area mainly due to the herding/grazing system practiced. The average age at first mating, age at first calving and calving interval of Somali cattle were 3.25 years, 4.05 years and 16.56 months, respectively. The mean daily milk yield and lactation length were 2.22 liters and 8.05 months, respectively. The Reproductive and productive performance of the Somali cattle excels that of other local cattle breeds. It was often characterized by early maturity, short calving interval and better milk yield. In addition, the breed could be considered as one of the few capable of surviving under the very harsh environment and producing under limited level of nutrition and management conditions. The major constraints for cattle production in study districts were feed shortage, disease, water scarcity, lack of veterinary services, marketing problem and predator. Among those constraints inadequate supply of quality feed, diseases and water shortage were the main reasons for low productivity of the indigenous cattle breeds and are the major factors limiting cattle productivity in the study districts. Therefore, to sustain the production system in the study areas the following points are recommended:

- Improve the current condition of communal rangelands through management of degraded areas by awareness creation on the value of these common resources and development of rules and regulation to sustain the existing resource and implement over the utilization of communal/pastoral rangeland management systems to reduce constraints such as shortage of feed, drought and grazing land deterioration which perpetuated through time due to land-use changes and seasonal fluctuation.

- Awareness creation to minimize feed shortage through conservation of forage/pasture in the form of hay at the end of rainy season due to abundant pasture existence in wet season. However, lack of experience in haymaking hinders the practice. Hence, due consideration should be given to train the farmers in haymaking and feed conservation practices.

- Further research and development work should be encouraged to alleviate 
dry season feed shortage through different options such as the utilization of non-conventional feeds, forages development program, use of irrigation, alternative means of crop residue utilization and conservation practices.

- The government should give priority to constructing and/or rehabilitating ponds; underground water storage and other infrastructure for the collection and storage of rainwater.

- Improve animal health service delivery including training, increasing health service centers and drug supply system with close monitoring and supervision.

- Provision of strong extension services to farmers for feed resource development and training them in basic principles of collection, storage of harvested feed resources and crop residues should be sought.

\section{Acknowledgements}

The authors would like to thank Jigjiga University for funding the research.

\section{Conflicts of Interest}

The authors declare no conflicts of interest regarding the publication of this paper.

\section{References}

[1] Behnke, R. and Metaferia, F. (2011) The Contribution of Livestock to the Ethiopian Economy-Part II. IGAD LPI Working Paper 02-11. IGAD Livestock Policy Initiative, Addis Ababa. https://hdl.handle.net/10568/24969

[2] CSA (Central Statistical Agency) (2020) Agricultural Sample Survey. Report on Livestock and Livestock Characteristics. Volume II. Statistical Bulletin 587. Addis Ababa, 9-11.

[3] FAO (Food and Agriculture Organization of the United States) (2000) The Appropriateness, Significance and Application of Biotechnology Options in the Animal Agriculture of the Developing Countries. Electronics Forum on Biotechnology in Food and Agriculture. http://www.fao.org/biotech/C3doc.htm

[4] Shiferaw, Y., Tenhagn, B., Bekana, M. and Kassa, T. (2003) Reproductive Performance of Crossbred Dairy Cows in Different Production Systems in the Central Highlands of Ethiopia.

[5] Yigezu, Z. (2003) Challenges and Opportunities of Livestock Marketing in Ethiopia. Proceedings of the 10 Annual Conference of Ethiopian Society of Animal Production (ESAP), Addis Ababa, 22-24 August 2002, 47-54.

[6] Lobago, F., Bekana, M., Gustafsson, H. and Kindahl, H. (2007) Longitudinal Observation on Reproductive and Lactation Performances of Smallholder Crossbred Dairy Cattle in Fitche, Oromia Region, Central Ethiopia. Tropical Animal Health and Production, 39, 395-403. https://doi.org/10.1007/s11250-007-9027-z

[7] Aynalem, H., Workneh, A., Noah, K., Tadele, D. and Azage, T. (2011) Breeding Strategy to Improve Ethiopian Boran Cattle for Meat and Milk Production. IPMS (Improving Productivity and Market Success) of Ethiopian Farmers Project. Working Paper No. 26. ILRI (International Livestock Research Institute), Nairobi.

[8] NMA (2013) National Metrological Agency; Jigjiga Metrological Branch Directorate 
Data.

[9] Musa, L.M., Peters, K.J. and Ahmed, M.K.A. (2006) On Farm Characterization of Butana and Kenana Cattle Breed Production Systems in Sudan. Livestock Research for Rural Development, 18, 56-61.

[10] Guyo, S., Tamir, B. and Robe, B. (2014) Assessment of Cattle Husbandry Practices in Burji Woreda, Segen Zuria Zone of SNNPRS, Ethiopia.

[11] Gebreegziabher, Z., Merkine, M. and Mathewos, S. (2016) Assessment of Goat Production Systems and Factors Affecting Production and Utilization of Goat's Milk in Humbo District of Wolaita Zone, Southern Ethiopia. Journal of Biology, Agriculture and Healthcare, 6, 46-51.

[12] Wendimu, B. (2013) On-farm Phenotypic Characterization of Black Head Somali Sheep and Their Role for Pastoral and Agro-Pastoral Community in Gode Zone, Somali Region. An MSc Thesis, The School of Graduate Studies of Haramaya University, Haramaya.

[13] Kerealem, E. (2005) Honeybee Production System, Opportunities and Challenges in EnebseSar Midir Woreda (Amhara Region) and Amaro Special Wereda (Southern Nations, Nationalities and Peoples Regional State), Ethiopia. MSc. Thesis, Alemaya University, Alemaya, 133.

[14] Scarpa, R., Ruto, E., Kristjanson, P., Radeny, M., Drucker, A. and Rege, E. (2003) Valuing Indigenous Cattle Breeds in Kenya: An Empirical Comparison of Stated and Revealed Preference Value Estimates. Ecological Economics, 45, 409-426. https://doi.org/10.1016/S0921-8009(03)00094-6

[15] Teshome, A., Abule, E. and Lisanework, N. (2010) Traditional Rangeland Resource Utilization Practices and Pastoralists' Perception on Land Degradation in South-East Ethiopia. Tropical Grasslands, 44, 202-212.

[16] Alemayehu, M. (2005) Rangelands Biodiversity: Concepts, Approaches, and the Way Forward. Addis Ababa University, Addis Ababa.

[17] Vernooij, A. (2007) Report Ethiopia Mission, Internal Report 2007. Animal Sciences Group, Wageningen University. Veterinary Journal Wageningen UR Livestock Research, Lelystad, 1-2.

[18] Tesfaye, M. (2007) Characterization of Cattle Milk and Meat Production, Processing and Marketing System in Metema District, Ethiopia. M.Sc. Thesis, Hawassa University, Awassa.

[19] Tilahun, S., Vijchulata, P., Chairatanayuth, P. and Swasdiphanich, S. (2006) Assessment of Small Ruminant Management Practices in Jijiga and Shinile Zones of Somali Regional State, Ethiopia.

[20] IPS (International Project Service) (2000) Resource Potential Assessment and Project Identification Study of the Somalia Region: Socio-Economic Assessment. Investment Office of the Somalia Regional State. Research Report. 3:51.

[21] Fikru, S. and Omer, A.A. (2015) Traditional Small Ruminant Production and Management Practices in Awbare District of Ethiopian Somali Regional State. Journal of Animal Production Advances, 5, 697-704. https://doi.org/10.5455/japa.20150626043822

[22] Philimon, T., Kidanie, D., Endeshaw, T., Ashebir, K., Abebe, T., Weldegebrial, G.E., Workinesh, S. and Mariam, W.T. (2016) Study on Cattle Management and Marketing Practices in Afar Region. International Journal of Livestock Production, 7, 55-65. https://doi.org/10.5897/IJLP2015.0262

[23] Mulugeta, F. (2015) Production System and Phenotypic Characterization of Begait 
Cattle, and Effects of Supplementation with Concentrate Feeds on Milk Yield and Composition of Begait Cows in Humera Ranch, Western Tigray, Ethiopia. PhD Dissertation, Addis Ababa University, Addis Ababa.

[24] Köhler, R. and Ober, R. (2000) Management of Animal Genetic Diversity at Community Level. Deutsche Gesellschaft für Technische Zusammenarbeit (GTZ) GmbH.

[25] Takele, T. (2005) On Farm Phenotypic Characterization of Sheko Breed of Cattle and Their Habitat in Bench maji Zone, Ethiopia. MSc Thesis, Alemaya University, Alemaya.

[26] Merha, Z. (2006) Genetic Diversity in Northern Ethiopian Cattle Breed: On-Farm and Molecular Characterization. PhD Dissertation, Agricultural University, Wageningen.

[27] Al-Amin, M., Nahar, A., Bhuiyan, A. and Faruque, M. (2007) On-Farm Characterization and Present Status of North Bengal Grey Cattle in Bangladesh. Department of Animal Breeding and Genetics, Bangladesh Agricultural University, and Department of Dairy Science, Bangladesh Agricultural University, Bangladesh. https://doi.org/10.1017/S1014233900002194

[28] Masama, E., Kusina, N., Sibanda, S. and Majoni, C. (2003) Reproduction and Lactational Performance of Cattle in a Smallholder Dairy System in Zimbabwe. Tropical Animal Health and Production, 35, 117-129. https://doi.org/10.1023/A:1022821418031

[29] Workneh, A. and Rowlands, J. (2004) Design, Execution and Analysis of the Livestock Breed Survey in Oromiya Regional State, Ethiopia. OADB (Oromia Agricultural Development Bureau), Addis Ababa and ILRI (International Livestock Research Institute), Nairobi, 260.

[30] Dereje, T., Workneh, A. and Hedge, B. (2005) Survey of Traditional Cattle Production Systems and Preferred Cattle Functions in North and South Wollo Zones, Ethiopia. Ethiopian Veterinary Journal, 9, 91-108.

[31] Kedija, H. (2008) Characterization of Milk Production System and Opportunity for Market Orientation: A Case Study of Mieso District, Oromia Region, Ethiopia. MSc Thesis, Haramaya University, Haramaya.

[32] Kedir, J., Abdinasir, A., Habtamu, A., Nejib, A., Hassen, M., Sied, M. and Mohammed, I. (2016) The Contribution of Milk to the Pastoralist Economy in the Ethiopian Somali Regional State. 